\title{
Networked Scholarship and Motivations for Social Media use in Scholarly Communication
}

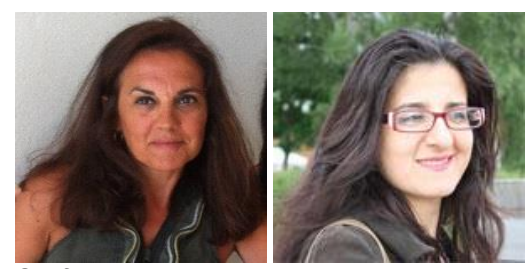

Stefania Manca and Maria Ranieri

Institute of Educational Technology, National Research Council of Italy, Department of Education and Psychology, University of Florence

\begin{abstract}
Research on scholars' use of social media suggests that these sites are increasingly being used to enhance scholarly communication by strengthening relationships, facilitating collaboration among peers, publishing and sharing research products, and discussing research topics in open and public formats. However, very few studies have investigated perceptions and attitudes towards social media use for scholarly communication of large cohorts of scholars at national level. This study investigates the reasons for using social media sites for scholarly communication among a large sample of Italian university scholars $(\mathrm{N}=6139)$ with the aim of analysing what factors mainly affect these attitudes. The motivations for using social media were analysed in connection with frequency of use and factors like gender, age, years of teaching, academic title, and disciplinary field. The results point out that for the most used tools the influence of the variables examined was higher in shaping scholars' motivations. In fact, frequency of use, age, years of teaching, and disciplinary field were found to be relevant factors especially for LinkedIn and ResearchGate-Academia.edu, while gender and academic title seemed to have a limited impact on scholars' motivations for all social media sites considered in the study. Considerations for future research are provided along with limitations of the study.
\end{abstract}

Keywords: digital scholarship, networked scholarship, social media, scholarly communication, higher education, academic staff

\section{Introduction}

Digital technology, in general, and social media, in particular, are progressively transforming research practice, working conditions, and professional identity of academic staff and researchers through digital and networked scholarship practices (Greenhow \& Gleason, 2014; Veletsianos, 2016; Weller, 2011). The four traditional dimensions of scholarship (discovery, integration, application, and teaching), as redefined by Boyer in his 9os seminal work (Boyer, 1990), have been increasingly affected by the values and the ideology of digital and open science aimed at promoting scholarly networking and public sharing of scientific knowledge among a wider public. Today, networked and distributed scholarship constitutes an emergent scholarly system that intersects 
mainstream academia with its own techno-cultural system (Stewart, 2015). It aligns with and exceeds Boyer's model for scholarship (Boyer, 1990) promoting practices of cross-disciplinarity, fostering public ties, and rewarding connectivism and collaboration (Stewart, 2015). From this perspective, digital scholarship relies on more inclusive approaches to the construction and sharing of knowledge and is affecting the practice of carrying out research investigation and scholars' public engagement (Weller, 2011). This change is not only influencing the way digital technologies are being incorporated into teaching and research, but is also leading to the promotion of the values of open science and global knowledge (Pearce, Weller, Scanlon, \& Ashleigh, 2010). In this scenario, also social media are being increasingly adopted by scholars to enhance open and networked scholarly communication due to their potential to create new and strengthen old relationships, to disseminate and discuss information in public format (Greenhow \& Gleason, 2014).

Several studies stressed how many researchers today are familiar with Web 2.0 tools like blogs, wikis, general and academic social network sites, and multimedia sharing, at all stages of the research lifecycle, from identifying research opportunities to disseminating final findings (Donelan, 2016; Gu \& Widén-Wulff, 2011; Lupton, 2014; Manca \& Ranieri, 2016b; Moran, Seaman, \& Tinti-Kane, 2012; Rowlands, Nicholas, Russell, Canty, \& Watkinson, 2011).

However, according to Veletsianos (2016), the evidence that describes scholars' experiences in social media sites are fragmented and not well understood, demanding more focused research on the day-to-day realities of social media for scholarship. Goodfellow (2013) pointed out how the three dimensions of scholarly practice scholarship, openness, and digitality - seem to resemble an impossible triangle that creates tensions in practice, especially when confronting issues of openness. Challenges in the scholarly use of social media were also reported by Scanlon (2014) and Stewart (2015), who stressed how institutional policies tend to discourage scholars from unconventional publishing practices. Moreover, today network engagement is progressively involving individuals rather than roles or institutions and creating an emergent scholarly system of its own. Scholars are becoming part of an increasingly complex academic system, with its own values and demanding new responses to both internal and external new stimuli (Veletsianos \& Kimmons, 2012).

In this complex scenario, this study aims to contribute to the current debate about networked scholarship and social media use in scholarly practice focusing on the motivations of a large cohort of Italian university scholars for using social media in scholarly communication. The study's scope encompasses the broad range of knowledge related to social media use among academics located in a specific country and seeks to advance knowledge on how digital tools and social media are increasingly affecting scholarly inquiry and communication (Stewart, 2015; Veletsianos, 2016; Weller, 2011).

This paper is part of a larger study whose aim was to investigate use of social media sites for personal, teaching and professional purposes through a survey addressed to the entire Italian university population. The relationship and the factors that affect the three types of use were investigated in Manca and Ranieri (2016b), and a specific focus on reasons and obstacles in teaching use was reported in Manca and Ranieri (2016a). An additional publication was devoted to exploring use of social media for scholarly communication by investigating the extent to which Italian academics use social media sites, which social media tools were perceived as the most valuable, and the main reasons for using social media in academic practice (Manca \& Ranieri, 2017). This study investigates in depth the issue of motivations and their relationship with extent of use, and with a number of factors such as age, gender, numbers of years of teaching, academic title, and field of knowledge.

In the following, we first introduce the review of the literature and the methodological framework of the study, and then we describe and discuss the results and their implications for future research. 


\section{Related Literature}

\section{Reasons for using Social Media Sites for Scholarly Purposes}

Published research that examines academic social media practices highlighted several motivations for their scholarly usage (Al-Aufi \& Fulton, 2015; Donelan, 2016; El-Berry, 2015; Elsayed, 2016; Gruzd \& Goertzen, 2013; Jamali, Nicholas, \& Herman, 2016; Jeng, He, \& Jiang, 2015; Lupton, 2014; Manca \& Ranieri, 2017; Nández \& Borrego, 2013; Nentwick \& König, 2014; Niyazov et al., 2016). Manca and Ranieri (2017) found that Italian scholars are using social media to keep up to date, maintain and strengthen networks, and increase visibility with positive implications for career progression. In a similar vein, Donelan (2016) reported that the main motivations for expert communicators and versatile users were self-development, and maintaining and widening networks, while introvert users were mainly externally driven. The author also found that with increasing levels of activity the number of motivations increase, as does the perceived number of successful outcomes. Lupton (2014) identified Twitter, LinkedIn, Academia.edu, Facebook, ResearchGate, blogs, and YouTube as more popular for academic work and among benefits he found making connections and developing networks, openness and sharing, self-promotion, and support as most prominent. In a study on Irish and Omani institutions, Al-Aufi and Fulton (2015) reported that Facebook, Twitter and Google+ were the most common sites especially for international communication and collaboration. Similarly, Nentwick and König (2014) found that informal platforms like Facebook are suitable for public relations, academic organizations, scholarly associations, and networks, as well as for individual scholars. Informal social networks are also used to gather information, collaboration and a mixture of socializing and information dissemination (Gruzd \& Goertzen, 2013).

Academic social network sites (ASNS) like Academia.edu and ResearchGate are generally employed to get in touch with other scholars, disseminate research results, and establish new connections with colleagues (Elsayed, 2016; Nández \& Borrego, 2013). ASNS are also used to discover recommended research papers, follow discussion groups and track metrics relating to interest in their work (El-Berry, 2015). For instance, a recent study carried out in Academia.edu (Niyazov et al., 2016) found that papers uploaded to this site receive a $69 \%$ boost in citations over five years, while Jamali, Nicholas, and Herman (2016) reported that ResearchGate is highly used since, in terms of reputation, it is the most complete academic platform. Finally, Jeng, He, and Jiang (2015) pointed out that Mendeley's users who were member of more groups seemed to be more motivated to increase their professional visibility.

\section{Differences across Age, Gender, and Scientific Discipline}

In the context of scholarly practices and social media adoption, research has identified age, gender, and discipline as potential sources of variation, although to different degrees. In this section, we summarize some of the existing research findings related to these variables.

Scholars' age. Several studies found that age is an important factor influencing social media adoption, with early-career scholars showing higher rates of use than their older counterparts (Dahlstrom, 2012; Moran et al., 2012; Segado-Boj, Chaparro Dommarro, \& Castillo-Rodríguez, 2015; Stewart, 2015; Zhu, 2014). Other studies (Manca \& Ranieri, 2016b; Nández \& Borrego, 2013) brought to more nuanced conclusions, with younger scholars more inclined to use social network sites and older scholars more interested in conferencing systems, images, and videos. Further findings (Harley, Acord, Earl-Novell, Lawrence, \& King, 2010; Procter et al., 2010) seem not to confirm that age is a significant predictor, while some studies suggest that higher usage is associated with older age groups (Procter et al., 2010), or with higher relevance within the network (Jordan, 2014). 
Gender issues. Overall, gender seems to be a poor predictor of social media use in scholarly context (Manca \& Ranieri, 2016b; Nández \& Borrego, 2013), although some slight differences have been reported according to the tools. For example, Zhu (2014) found that females are more inclined to adopt microblogging tools, while men prefer wikis. On the other hand, Rowlands, Nicholas, Russell, Canty, and Watkinson (2011) reported that men have a higher preference for LinkedIn. However, some studies suggest that other factors such as age and scientific domain are also important, when exploring genders issues (Thelwall \& Kousha, 2014; Zhu, 2014).

Scientific discipline. Many studies reported that scholars in Humanities and Social Sciences are more prone to embrace social media for scholarly usage than their colleagues in the Science disciplines (AlAufi \& Genoni, 2010; Almousa, 2011; Costa, 2013; Kieslinger, 2015; Moran et al., 2012; Nández \& Borrego, 2013; Procter et al., 2010). On the contrary, other studies documented different social media practices according to the main research subject (Costa, 2013; Goodfellow, 2013; Jordan, 2014; Ortega, 2015; Zhu, 2014). For example, in a study on the use of ASNS among Spanish researchers, Ortega (2015) found that Academia.edu was extremely popular among humanists and social scientists, while biologists opted for ResearchGate. At the same time, there are also studies reporting higher usage rate of social media in scientific disciplines (Maron \& Smith, 2008; Elsayed, 2016; Procter et al., 2010). However, even though results on this factor are not always consistent in terms of which specific discipline is associated with higher use or with specific practices, discipline still remains a significant factor influencing social media adoption for scholarly purposes (Manca \& Ranieri, 2016b).

\section{Rationale of the Study and Research Question}

This study provides a timely exploration into how Italian university scholars use social media sites in scholarly communication by analysing the association between motivations to use these sites and a number of socioprofessional factors such as age, gender, numbers of years of teaching, academic title, and field of knowledge. It extends some previous work on social media use in academia that investigated the extent to which Italian academics use social media sites for professional purposes; how influential personal and professional factors were in shaping the frequency of social media use; what social media tools were perceived as the most valuable; and the main reasons for using social media in academic practice (Manca \& Ranieri, 2017). This study investigates in depth the issue of motivations and aims to provide an answer to the following research question:

How influential are factors such as frequency of use, academic field, academic title, numbers of years of teaching, gender, and age in shaping the motivations of social media use in scholarly communication?

\section{Method}

\section{Tool and Context of the Study}

This study was conducted on the results of an online survey tool that was addressed to all Italian university scholars during the October-December 2013 period. The aim was to investigate how Italian academic staff use social media tools for personal, teaching, and professional development purposes. The survey was addressed to faculty staff that had a permanent or a tenured track position, such as assistant professors, associate 
professors, and full professors. The population was recruited through the Ministry of Education records that do not maintain positions of PhD students, post-doc students, or graduate students.

The survey was adapted and translated from a survey tool administered by Pearson and the Babson Survey Research Group to faculty staff in the USA (Moran, Seaman, \& Tinti-Kane, 2012). The tool was modified for application in the Italian context, and a number of new questions about the organizational dimension were added. Specific items were also added regarding detailed use and motivations of use of social media tools, in terms of personal, teaching, and professional purposes. The final tool was composed mostly of closed questions that include an open field for respondents to explain their responses.

The survey was implemented online through LimeSurvey (http://www.limesurvey.org/), an open source platform, and invitations to compile were sent via email. A detailed account of the construction and validation of the survey tool, and of the recruitment of participants and administration procedures, is reported in Manca and Ranieri (2016a). The complete survey tool is available in Manca (2014).

Respondents were asked to provide answers with reference to the use of blogs and micro-blog services like Twitter; general social network sites like Facebook; professional and academic social networking services like LinkedIn, ResearchGate, and Academia.edu; content sharing and multimedia services like podcasts, wikis, YouTube, and Vimeo; and SlideShare. They were also provided with definitions of personal use (i.e., use of social media to connect with family and friends), teaching use (i.e., use of social media to research a topic, include in a lecture, as part of a student assignment, etc.), and professional use (i.e.; use of social media to connect with colleagues, stay up to date on areas of professional interest, etc.).

With regard to the above-mentioned use types, the topic of scholarly communication is considered part of the third type of use (professional). For the purpose of this study, the motivations for using social media for scholarly purposes were investigated via a specific question ("For each of the following tools (if any), what is the most important motivation for use") and items were identified as: "To keep in touch with my colleagues," "To extend my professional network," "To share professional interests," "To give visibility to my professional results," "To promote initiatives related to my job," "To be part of a professional community," and "Other motivation." Respondents were asked to provide a single choice. The reason why participants were asked to provide a single answer relies on the fact that we wanted to investigate the most important reason for scholars' adoption of social media in professional development. The items were constructed based on the review of the literature which indicates common motivations to adopt social media for scholarly practice.

Out of 58,175 subjects involved, 6139 completed the survey, corresponding to a response rate of $10.5 \%$. Only surveys that were filled at least for the frequency of use in the three types (personal, teaching, and professional) were considered. The relationship and the factors that affect the three types of use were investigated in Manca and Ranieri (2016b), and teaching practice, reasons and obstacles in teaching use in Manca and Ranieri (2016a).

\section{Sample and Data Analysis}

At a preliminary stage, a first quantitative analysis was carried out to compare the collected sample and the population addressed by the survey through a number of Chi-square tests. The results of these analyses showed that the sample overlapped the population on socio-demographic variables like gender, academic title, and scientific discipline. Data related to age and number of years of teaching could not be tested due to lack of similar data for the entire population. For a complete report of statistical analysis, see Manca and Ranieri (2016b). In Table 1, statistics related to socio-demographic and professional variables of the sample are reported. 
Table 1

Socio-Demographics and Professional Characteristics of the Sample (N=6139)

\begin{tabular}{lll}
\hline Gender & Male & $3727(60.7 \%)$ \\
& Female & $2412(39.3 \%)$ \\
\hline \multirow{2}{*}{$\begin{array}{l}\text { Academic title } \\
\text { N=6043) }\end{array}$} & Assistant Professor & $3130(51.8 \%)$ \\
& Associate Professor & $1704(28.2 \%)$ \\
& Full Professor & $1209(20.0 \%)$ \\
\hline & Mathematics and Computer & \\
& Science + & $1651(26.9 \%)$ \\
& Natural Sciences (MCSN) & \\
Scientific discipline & Professions and Applied & $1957(31.9 \%)$ \\
& Sciences (PAS) & \\
& Humanities and Arts + & $2531(41.2 \%)$ \\
& Social Sciences (HASS) & \\
\hline & Less than 25 & $0(0.0 \%)$ \\
Age & $25-34$ & $253(4.1 \%)$ \\
& $35-44$ & $1939(31.6 \%)$ \\
& $45^{-55}$ & $2185(35.6 \%)$ \\
Years of teaching & $55^{+}$ & $1762(28.7 \%)$ \\
\hline experience & Less than 5 & $722(11.8 \%)$ \\
& $5-10$ & $1047(17.1 \%)$ \\
& $10-20$ & $2512(40.9 \%)$ \\
& $20+$ & $1858(30.3 \%)$ \\
\hline
\end{tabular}

In this study, descriptive and inferential statistics to elaborate data to provide answers to the research question were carried out (Weisberg \& Bowen, 1977). The IBM Statistical Package for Social Sciences (SPSS 18.0) was used.

\section{Results}

\section{Preliminary Results}

Frequency of use of social media for scholarly practice was measured through a five-point scale (daily, weekly, monthly, rarely, do not use). Out of 6139 respondents, 4575 (74.5\%) reported that they use at least one tool. However, this data decreases to 3604 (58.7\%) if at least monthly use is considered.

As pointed out in Table 2, the most used tools are ResearchGate-Academia.edu, used by 3097 respondents (50.4\%), and LinkedIn, used by 2326 respondents (37.9\%). However, distribution of frequency of use reveals that the highest percentage of ResearchGate-Academia.edu use falls under weekly (16.3\%) use, while use of LinkedIn is much rarer ("rarely" accounts for $16.5 \%$ of use). YouTube and Vimeo use was rated by 1943 respondents (31.7\%) and Blog and Wiki use by 1764 respondents (28.7\%). Facebook was reported as used for scholarly reasons by 1393 respondents (22.7\%). 
Table 2

Frequency of Scholarly Use (N=6139)

\begin{tabular}{|c|c|c|c|c|c|c|}
\hline & Daily & Weekly & Monthly & Rarely & Do not use & TOT \\
\hline Twitter & $98(1.6 \%)$ & $142(2.3 \%)$ & $104(1.7 \%)$ & $261(4 \cdot 3 \%)$ & $\begin{array}{l}5534 \\
(90.1 \%)\end{array}$ & $\begin{array}{l}6139 \\
(100 \%)\end{array}$ \\
\hline Facebook & $237(3.9 \%)$ & $374(6.1 \%)$ & $279(4.5 \%)$ & $503(8.2 \%)$ & $\begin{array}{l}4746 \\
(77 \cdot 3 \%)\end{array}$ & $\begin{array}{l}6139 \\
(100 \%)\end{array}$ \\
\hline LinkedIn & $145(2.4 \%)$ & $539(8.8 \%)$ & $\begin{array}{l}631 \\
(10.3 \%)\end{array}$ & $\begin{array}{l}1011 \\
(16.5 \%)\end{array}$ & $\begin{array}{l}3813 \\
(62.1 \%)\end{array}$ & $\begin{array}{l}6139 \\
(100 \%)\end{array}$ \\
\hline Podcast & $28(0.5 \%)$ & $75(1.2 \%)$ & $101(1.6 \%)$ & $290(4.7 \%)$ & $\begin{array}{l}5645 \\
\text { (92.0\%) }\end{array}$ & $\begin{array}{l}6139 \\
(100 \%)\end{array}$ \\
\hline Blog-Wiki & $222(3.6 \%)$ & $483(7.9 \%)$ & 498 (8.1\%) & $561(9.1 \%)$ & $\begin{array}{l}4375 \\
(71.3 \%)\end{array}$ & $\begin{array}{l}6139 \\
(100 \%)\end{array}$ \\
\hline $\begin{array}{l}\text { YouTube- } \\
\text { Vimeo }\end{array}$ & 117 (1.9\%) & $410(6.7 \%)$ & $521(8.5 \%)$ & $\begin{array}{l}895 \\
(14.6 \%)\end{array}$ & $\begin{array}{l}4196 \\
(68.3 \%)\end{array}$ & $\begin{array}{l}6139 \\
(100 \%)\end{array}$ \\
\hline $\begin{array}{l}\text { ResearchGate- } \\
\text { Academia.edu }\end{array}$ & $319(5.2 \%)$ & $\begin{array}{l}999 \\
(16.3 \%)\end{array}$ & $\begin{array}{l}875 \\
(14.3 \%)\end{array}$ & $\begin{array}{l}904 \\
(14.7 \%)\end{array}$ & $\begin{array}{l}3042 \\
(49.6 \%)\end{array}$ & $\begin{array}{l}6139 \\
(100 \%)\end{array}$ \\
\hline SlideShare & $47(0.8 \%)$ & $142(2.3 \%)$ & $245(4.0 \%)$ & $444(7.2 \%)$ & $\begin{array}{l}5261 \\
(85.7 \%) 7\end{array}$ & $\begin{array}{l}6139 \\
(100 \%)\end{array}$ \\
\hline
\end{tabular}

Motivations to use social media were rated for each tool. The complete data are reported in Table 3 . Respondents rated Facebook mostly to "Keep in touch with colleagues" (42.9\%), while LinkedIn was mainly valued to "Extend the professional network" (51.0\%). Twitter, Podcasts, Blogs-Wikis, YouTube-Vimeo, and SlideShare were mostly related to "Share professional interests" $(32.1 \%, 34.4 \%, 35.3 \%, 28.8 \%$, and $32.6 \%$ respectively). Finally, ResearchGate and Academia.edu were related to the possibility of "Giving visibility to professional results" (40.4\%), to "Extend professional networks" (18.8\%), and to "Share professional interests" (17.6\%).

Table 3

Motivations to use Social Media

\begin{tabular}{|c|c|c|c|c|c|c|c|}
\hline & $\begin{array}{l}\text { To keep in } \\
\text { touch with } \\
\text { my } \\
\text { colleagues }\end{array}$ & $\begin{array}{l}\text { To extend } \\
\text { my } \\
\text { profess- } \\
\text { ional } \\
\text { network }\end{array}$ & $\begin{array}{l}\text { To share } \\
\text { profession } \\
\text { al interests }\end{array}$ & $\begin{array}{l}\text { To give } \\
\text { visibility to } \\
\text { my } \\
\text { profess- } \\
\text { ional } \\
\text { results }\end{array}$ & $\begin{array}{l}\text { To } \\
\text { promote } \\
\text { initiatives } \\
\text { related to } \\
\text { my job }\end{array}$ & $\begin{array}{l}\text { To be part } \\
\text { of a } \\
\text { profess- } \\
\text { ional } \\
\text { commun- } \\
\text { ity }\end{array}$ & $\begin{array}{l}\text { Other } \\
\text { motivation }\end{array}$ \\
\hline Twitter $(\mathrm{N}=589)$ & $\begin{array}{l}105 \\
(17.8 \%)\end{array}$ & $75(12.7 \%)$ & $\begin{array}{l}189 \\
(32.1 \%)\end{array}$ & $56(9.5 \%)$ & $87(14.8 \%)$ & $39(6.6 \%)$ & $38(6.5 \%)$ \\
\hline $\begin{array}{l}\text { Facebook } \\
(\mathrm{N}=1166)\end{array}$ & $\begin{array}{l}550 \\
(42.9 \%)\end{array}$ & $\begin{array}{l}134 \\
(11.5 \%)\end{array}$ & $\begin{array}{l}193 \\
(16.6 \%)\end{array}$ & $77(6.6 \%)$ & $\begin{array}{l}183 \\
(15.7 \%)\end{array}$ & $46(3.9 \%)$ & $33(2.8 \%)$ \\
\hline $\begin{array}{l}\text { LinkedIn } \\
(\mathrm{N}=1865)\end{array}$ & $\begin{array}{l}405 \\
(21.7 \%)\end{array}$ & $\begin{array}{l}952 \\
(51.0 \%)\end{array}$ & $\begin{array}{l}193 \\
(10.3 \%)\end{array}$ & $127(6.8 \%)$ & $60(3.2 \%)$ & $106(5.7 \%)$ & $22(1.2 \%)$ \\
\hline Podcast $(\mathrm{N}=209)$ & $11(5 \cdot 3 \%)$ & $17(8.1 \%)$ & $72(34.4 \%)$ & $27(12.9 \%)$ & $32(15 \cdot 3 \%)$ & $15(7.2 \%)$ & $35(16.7 \%)$ \\
\hline $\begin{array}{l}\text { Blog-Wiki } \\
(\mathrm{N}=713)\end{array}$ & $50(7.0 \%)$ & $42(5.9 \%)$ & $\begin{array}{l}252 \\
(35 \cdot 3 \%)\end{array}$ & $11(16.0 \%)$ & $95(13.3 \%)$ & $65(9.1 \%)$ & $95(13.3 \%)$ \\
\hline
\end{tabular}




\begin{tabular}{llllllll}
$\begin{array}{l}\text { YouTube-Vimeo } \\
\text { (N=750) }\end{array}$ & $30(4.0 \%)$ & $59(7.9 \%)$ & $\begin{array}{l}216 \\
(28.8 \%)\end{array}$ & $\begin{array}{l}154 \\
(20.5 \%)\end{array}$ & $117(15.6 \%)$ & $39(5.2 \%)$ & $\begin{array}{l}135 \\
(18.0 \%)\end{array}$ \\
$\begin{array}{l}\text { ResearchGate- } \\
\begin{array}{l}\text { Academia.edu } \\
\text { (N=1989) }\end{array}\end{array}$ & $169(8.5 \%)$ & $\begin{array}{l}374 \\
(18.8 \%)\end{array}$ & $\begin{array}{l}350 \\
(17.6 \%)\end{array}$ & $\begin{array}{l}803 \\
(40.4 \%)\end{array}$ & $73(3.7 \%)$ & $170(8.5 \%)$ & $50(2.5 \%)$ \\
$\begin{array}{l}\text { SlideShare } \\
(\mathrm{N}=463)\end{array}$ & $31(6.7 \%)$ & $25(5.4 \%)$ & $\begin{array}{l}151 \\
(32.6 \%)\end{array}$ & $\begin{array}{l}120 \\
(25.9 \%)\end{array}$ & $53(11.4 \%)$ & $28(6.0 \%)$ & $55(11.9 \%)$ \\
\hline
\end{tabular}

\section{Influence of Frequency of Use and Socio-Professional Variables in Shaping Motivations}

A number of Chi-square tests were performed to examine the association between motivations, frequency of use (daily, weekly, monthly, rarely), scientific discipline (Mathematics and Computer Science + Natural Sciences - MCSN; Professions and Applied Sciences - PAS; Humanities and Arts + Social Sciences - HASS), academic title (assistant professor, associate professor, full professor), years of teaching (less than 5, 5-10, 1020, 20+), age $\left(25-34,35^{-44}, 45^{-55}, 55^{+}\right)$, and gender (male, female). Table 4 reports results of cross-tabs analysis and level of significance.

Table 4

Motivations, Frequency of Use, Social, and Professional Variables Tested Through Chi-Square Tests

\begin{tabular}{|c|c|c|c|c|c|c|}
\hline $\begin{array}{l}\text { Motivations } \\
\text { for use } \\
\end{array}$ & $\begin{array}{l}\text { Frequency of } \\
\text { use }\end{array}$ & $\begin{array}{l}\text { Scientific } \\
\text { discipline } \\
\end{array}$ & $\begin{array}{l}\text { Academic } \\
\text { title }\end{array}$ & $\begin{array}{l}\text { Years of } \\
\text { teaching }\end{array}$ & Age & Gender \\
\hline Twitter & $\begin{array}{l}X^{2}(18, \mathrm{~N}=382 \\
)=33.64 \\
p=.014^{*}\end{array}$ & $\begin{array}{l}X^{2}(12, \mathrm{~N}=589) \\
=12.16 \\
\mathrm{p}=.433\end{array}$ & $\begin{array}{l}X^{2}(12, \mathrm{~N}=571) \\
=11.03 \\
\mathrm{p}=.526\end{array}$ & $\begin{array}{l}X^{2}(18, N=589 \\
)=23.84 \\
p=.160\end{array}$ & $\begin{array}{l}X^{2}(18, N=589 \\
)=25 \cdot 38 \\
p=.115\end{array}$ & $\begin{array}{l}X^{2}(6, \mathrm{~N}=589) \\
=9.96 \\
\mathrm{p}=.126\end{array}$ \\
\hline Facebook & $\begin{array}{l}X^{2}(18, \mathrm{~N}=846 \\
)=28.07 \\
p=.061\end{array}$ & $\begin{array}{l}X^{2}(12, \mathrm{~N}=1166 \\
)=28.80 \\
\mathrm{p}=.004^{* *}\end{array}$ & $\begin{array}{l}X^{2}(12, \mathrm{~N}=1137 \\
)=10.37 \\
\mathrm{p}=.584\end{array}$ & $\begin{array}{l}X^{2}(18, \mathrm{~N}=1166 \\
)=28.64 \\
\mathrm{p}=.053\end{array}$ & $\begin{array}{l}X^{2}(18, \mathrm{~N}=1166 \\
)=28.49 \\
\mathrm{p}=.055\end{array}$ & $\begin{array}{l}X^{2}(6, \mathrm{~N}=1166) \\
=17.11 \\
\mathrm{p}=.009^{* *}\end{array}$ \\
\hline LinkedIn & $\begin{array}{l}X^{2}(18, \mathrm{~N}=149 \\
6)=43.69 \\
\mathrm{p}=.001^{* * *}\end{array}$ & $\begin{array}{l}X^{2}(12, \mathrm{~N}=186 \\
5)=21.64 \\
\mathrm{p}=.042^{*}\end{array}$ & $\begin{array}{l}X^{2}(12, \mathrm{~N}=182 \\
5)=24.69 \\
\mathrm{p}=.016^{*}\end{array}$ & $\begin{array}{l}X^{2}(18, \mathrm{~N}=186 \\
5)=62.95 \\
\mathrm{p}=.000^{* * *}\end{array}$ & $\begin{array}{l}X^{2}(18, \mathrm{~N}=186 \\
5)=73.69 \\
\mathrm{p}=.000^{* * *}\end{array}$ & $\begin{array}{l}X^{2}(6, \mathrm{~N}=1865) \\
=22.05 \\
\mathrm{p}=.001^{* * *}\end{array}$ \\
\hline Podcast & $\begin{array}{l}X^{2}(18, \mathrm{~N}=118) \\
=12.24 \\
\mathrm{p}=.835\end{array}$ & $\begin{array}{l}\mathrm{X}^{2}(12, N=209 \\
)=17.45 \\
p=.134\end{array}$ & $\begin{array}{l}X^{2}(12, \mathrm{~N}=204 \\
)=8.52 \\
p=.743\end{array}$ & $\begin{array}{l}X^{2}(18, \mathrm{~N}=209 \\
)=18.78 \\
p=.406\end{array}$ & $\begin{array}{l}X^{2}(18, \mathrm{~N}=209 \\
)=14.13 \\
p=.720\end{array}$ & $\begin{array}{l}X^{2}(6, \mathrm{~N}=209) \\
=1.96 \\
\mathrm{p}=.923\end{array}$ \\
\hline Blog-Wiki & $\begin{array}{l}X^{2}(18, \mathrm{~N}=589 \\
)=18.51 \\
p=.422\end{array}$ & $\begin{array}{l}X^{2}(12, \mathrm{~N}=713) \\
=25.25 \\
\mathrm{p}=.014^{*}\end{array}$ & $\begin{array}{l}X^{2}(12, \mathrm{~N}=694) \\
=17.84 \\
\mathrm{p}=.121\end{array}$ & $\begin{array}{l}X^{2}(18, \mathrm{~N}=713) \\
=31.76 \\
\mathrm{p}=.023^{*}\end{array}$ & $\begin{array}{l}X^{2}(18, \mathrm{~N}=713) \\
=21.96 \\
\mathrm{p}=.234\end{array}$ & $\begin{array}{l}X^{2}(6, \mathrm{~N}=713) \\
=14.07 \\
\mathrm{p}=.029^{*}\end{array}$ \\
\hline $\begin{array}{l}\text { YouTube- } \\
\text { Vimeo }\end{array}$ & $\begin{array}{l}X^{2}(18, \mathrm{~N}=381) \\
=14 \cdot 32 \\
\mathrm{p}=.708\end{array}$ & $\begin{array}{l}X^{2}(12, \mathrm{~N}=750) \\
=21.07 \\
\mathrm{p}=.049^{*}\end{array}$ & $\begin{array}{l}X^{2}(12, \mathrm{~N}=727) \\
=9.43 \\
\mathrm{p}=.666\end{array}$ & $\begin{array}{l}X^{2}(18, \mathrm{~N}=750) \\
=12.66 \\
\mathrm{p}=.812\end{array}$ & $\begin{array}{l}X^{2}(18, \mathrm{~N}=750) \\
=13.49 \\
\mathrm{p}=.762\end{array}$ & $\begin{array}{l}X^{2}(6, \mathrm{~N}=750) \\
=12.60 \\
\mathrm{p}=.050\end{array}$ \\
\hline $\begin{array}{l}\text { ResearchGat } \\
\text { e- } \\
\text { Academia.ed } \\
\text { u }\end{array}$ & $\begin{array}{l}X^{2}(18, \mathrm{~N}=1754 \\
)=38.19 \\
\mathrm{p}=.004^{* *}\end{array}$ & $\begin{array}{l}X^{2}(12, \mathrm{~N}=198 \\
9)=28.51 \\
\mathrm{p}=.005^{* *}\end{array}$ & $\begin{array}{l}X^{2}(12, \mathrm{~N}=812) \\
=6.44 \\
\mathrm{p}=.893\end{array}$ & $\begin{array}{l}X^{2}(18, \mathrm{~N}=198 \\
9)=69 \cdot 50 \\
\mathrm{p}=.000^{* * *}\end{array}$ & $\begin{array}{l}X^{2}(18, \mathrm{~N}=198 \\
9)=97 \cdot 34 \\
\mathrm{p}=.000^{* * *}\end{array}$ & $\begin{array}{l}X^{2}(6, N=1989 \\
)=18.18 \\
p=.006^{* *}\end{array}$ \\
\hline SlideShare & $\begin{array}{l}X^{2}(18, \mathrm{~N}=347) \\
=11.86 \\
\mathrm{p}=.855\end{array}$ & $\begin{array}{l}X^{2}(12, \mathrm{~N}=463) \\
=18.57 \\
\mathrm{p}=.099\end{array}$ & $\begin{array}{l}X^{2}(12, \mathrm{~N}=448 \\
)=10.51 \\
\mathrm{p}=.571\end{array}$ & $\begin{array}{l}X^{2}(18, \mathrm{~N}=463 \\
)=28.32 \\
\mathrm{p}=.057\end{array}$ & $\begin{array}{l}X^{2}(18, \mathrm{~N}=463 \\
)=25.81 \\
p=.104\end{array}$ & $\begin{array}{l}X^{2}(6, \mathrm{~N}=463) \\
=4.6 \\
\mathrm{p}=.596\end{array}$ \\
\hline
\end{tabular}

\footnotetext{
$* *$ p $<.001$ (two-tailed)

${ }^{* *} \mathrm{p}<.01$ (two-tailed)

${ }^{*} \mathrm{p}<$.05 (two-tailed)
} 
The association between motivation and frequency of use shows that the variable was significant for Twitter, LinkedIn, and ResearchGate-Academia.edu. Adjusted standardized residuals were inspected and a critical value for $\mathrm{Z}$ for a two-tailed significance test of 2.20 was considered for significance. For Twitter, "To share professional interests" was represented more among those who use the site "rarely" (2.8), "To promote initiatives related to my job" was more relevant for those who use the site "weekly" (2.3), while the category "Other motivation" was more represented among those who use the site "rarely" (3.2) or "daily" (2.3). For LinkedIn use, categories "To keep in touch with my colleagues" (4.5) and "To extend my professional network" (3.2) were more represented among respondents that reported use "rarely." Categories "To give visibility to my professional results" (2.5) and "To promote initiatives related to my job" (2.3) were more relevant for those who use the site "daily." As far as ResearchGate-Academia.edu is concerned, motivations "To give visibility to my professional results" $(2.5 ; 2.5)$ and "Other motivation" $(4.2 ; 3.4)$ were more represented among respondents that reported use of the sites "rarely" and "weekly."

The association between motivation and scientific discipline shows that the variable was significant for Facebook, LinkedIn, Blog-Wiki, YouTube-Vimeo, and ResearchGate-Academia.edu. Adjusted standardized residuals were inspected and the critical value for $\mathrm{Z}$ for a two-tailed significance test of 2.03 was considered for significance. For Facebook, "To keep in touch with my colleagues" $(4.5 ; 3.3)$ was represented more in the MCSN and HASS groups, while the category "To give visibility to my professional results" (2.2) was more represented in the MCSN group. For LinkedIn use, the category "To extend my professional network" (2.7) was more represented in the PAS group, and category "To promote initiatives related to my job" (2.4) was more relevant for the HASS group. For Blog-Wiki use, the category "To extend my professional network" $(2.3 ; 3.5)$ was more represented in the HASS and PAS groups. For YouTube-Vimeo use, category "To keep in touch with my colleagues" (2.3) was more relevant for the MCSN group, while the category "To give visibility to my professional results" (2.5) was more represented in the PAS group. Lastly, for ResearchGate-Academia.edu, the category "To keep in touch with my colleagues" $(2.5 ; 2.2)$ was more represented in the MCSN and HASS groups, while the categories "To extend my professional network" (2.5) and "To share professional interests" (2.2) and "To promote initiatives related to my job" (2.1) were more represented in the HASS group.

As far as the association between motivations and academic title is concerned, the variables were associated only for LinkedIn. Adjusted standardized residuals were inspected and the critical value for $\mathrm{Z}$ for a two-tailed significance test of 2.03 was considered for significance. Motivations like "To extend my professional network" $(3.5 ; 2.5)$ and "To share professional interests" $(2.8 ; 3.0)$ were more significant for assistant professors and full professors. No significant association was found for the other sites.

The association between motivations and years of teaching was found significant for LinkedIn, Blog-Wiki, and ResearchGate-Academia.edu. Adjusted standardized residuals were inspected and the critical value for $\mathrm{Z}$ for a two-tailed significance test of 2.20 was considered for significance. For LinkedIn, motivations like "To keep in touch with my colleagues" (3.2), "To extend my professional network" (5.0), "To share professional interests" (3.5), and "To promote initiatives related to my job" (3.5) were more relevant for respondents with 20 years and more of teaching. For motivations "To extend my professional network" $(2.7 ; 2.8)$ and "To share professional interests" $(2.5 ; 2.6)$ significance was also found for scholars with less than five or with 5-10 years of teaching. In the case of Blog-Wiki, the motivation "To keep in touch with my colleagues" (2.3) was more relevant for respondents with 10-20 years of teaching, while "Other motivation" (3.6) was more relevant for those with 5-10 years of teaching. ResearchGate-Academia.edu was found relevant for scholars with 5-10 years of teaching with respect to "To give visibility to my professional results" (2.7), while for scholars with 20 years and more of teaching "To keep in touch with my colleagues" (3.1), "To extend my professional network" (2.9), 
"To share professional interests" (4.3), "To give visibility to my professional results" (5.0), "To promote initiatives related to my job" (3.5) and "Other motivation" (2.7) were all relevant.

Age was relevant only for LinkedIn and ResearchGate-Academia.edu use. Adjusted standardized residuals were inspected and the critical value for $\mathrm{Z}$ for a two-tailed significance test of 2.20 was considered for significance. For LinkedIn motivation "To keep in touch with my colleagues" (2.9) was relevant especially for scholars of 55 or more years old, "To extend my professional network" $(4.5 ; 5.2)$ for $35-44$ and $55^{+}$old respondents, and "To share professional interests" $(2.2 ; 4.1 ; 4.6)$ was relevant for $25-34,35-44$ and $55^{+}$groups. As far as ResearchGate-Academia.edu is concerned, the motivations "To keep in touch with my colleagues" (3.1; 3.3), "To share professional interests" ( $4.9 ; 4.9)$, "To give visibility to my professional results" $(5.7 ; 5.6)$ and "To promote initiatives related to my job" $(2.6 ; 3.5)$ were significantly associated with the $35-44$ and $55^{+}$ groups; whereas the motivation "To give visibility to my professional results" (2.4) was also relevant for the 25-34 group.

Lastly, gender was found significantly associated with the motivations for Facebook, LinkedIn, Blog-Wiki, and ResearchGate-Academia.edu. Adjusted standardized residuals were inspected and the critical value for $\mathrm{Z}$ for a two-tailed significance test of 1.73 was considered for significance. For Facebook, "To extend my professional network" (1.9), "To give visibility to my professional results" (2.2), and "To promote initiatives related to my job" (2.5) were more relevant for males, while "To be part of a professional community" (2.0) was significant for females. LinkedIn was found relevant for females as regards "To be part of a professional community" (3.5), while "Other motivation" (2.4) was more significant for males. In the case of Blog-Wiki, "To give visibility to my professional results" (3.5) was more relevant for males. Lastly, for ResearchGate-Academia.edu, the motivation "To keep in touch with my colleagues" (2.3) was more significant for males, while "To be part of a professional community" (3.5) was more relevant for females.

\section{Discussion}

This study was aimed at investigating the influence that factors such as frequency of use, academic field, academic title, number of years of teaching, gender, and age may have in shaping motivations for using social media for scholarly purposes.

As a first observation, we can notice that the influence of the variables examined in shaping motivations is higher for the most used tools. Among Italian scholars the most used social media sites for scholarly purposes were professional and academic social network sites such as ResearchGate-Academia.edu and LinkedIn. For both platforms all variables showed they have an influence on motivations, though to different degrees and with the exception of the academic title for ResearchGate-Academia.edu. On the other hand, Podcast was the least popular tool and in this case the variables under consideration did not show any influence on motivations for use. A similar pattern characterized SlideShare and Twitter. Although there is no clear-cut evidence of a linear trend, this might suggest that intense users have a less vague profile in terms of age, gender, discipline.. However, this could be further investigated through statistical measures like cluster analysis.

When coming to the association between motivations and specific factors, a varied picture emerged according to each tool. Overall, the frequency of use seems to have a limited impact with the exception of LinkedIn, ResearchGate-Academia.edu, and Twitter. In particular, those who are less familiar with LinkedIn declared they use the site to maintain contacts with colleagues and to enlarge professional networks as main reasons, while those who are more familiar declared they are interested in increasing visibility and promoting job- 
related activities. An explanation for this might be that self-promotion requires a more pro-active attitude on the web, though dissemination through social network sites is still considered as a moderately relevant activity contributing to reputation among scholars (Jamali, Nicholas, \& Herman, 2016).

Moving to scientific discipline, our study found that this factor was significant for Facebook, LinkedIn, BlogWiki, YouTube-Vimeo, and ResearchGate-Academia.edu. Rather than providing a polarized representation of academic digital practices with certain groups prevailing over others, our results show a varied picture of motivations and associated practices reflecting the diversity of the different conventions that characterize each academic discipline. In this, our study is consistent with previous works (Costa, 2013; Goodfellow, 2013; Jordan, 2014; Manca \& Ranieri, 2017; Ortega, 2015; Zhu, 2014) that reported different scholars' motivations and social media practices according to the scientific discipline. It is worth pointing out that, for example, in the case of LinkedIn the motivation "To extend my professional networks" is associated with scholars in PASS, while in the case of ResearchGate-Academia.edu it is linked to scholars in HASS. This seems to suggest that researchers in applied sciences are interested in less academic audiences, and this would be understandable and also consistent with their institutional mission.

While academic title was not found particularly relevant in shaping motivations, years of teaching showed significance for LinkedIn, Blog-Wiki, and ResearchGate-Academia.edu. In particular, we observed that, especially for ResearchGate-Academia.edu, the higher the number of years of teaching, the higher the number of motivations reported as relevant by respondents. Indeed, in the case of scholars with 20 years and more of teaching, there were several reasons for using ResearchGate-Academia.edu, ranging from maintaining and widening networks, to sharing professional interests, improving visibility and promoting professional initiatives. For younger scholars with less than five years or with 5-10 years of teaching, the use of ResearchGate-Academia.edu was relevant only to increase visibility of professional results. One might assume that scholars with fewer years of teaching are younger and explain these differences as a consequence of the greater popularity of senior scholars (Jordan, 2014; Thelwall \& Kousha, 2014). This could bring them to be even more active than their younger counterparts and use social media for a greater variety of reasons.

This trend is also confirmed by age, which was significant for LinkedIn and ResearchGate-Academia.edu. For 25-34 year-old scholars, the use of LinkedIn was relevant only for sharing professional interests and that of ResearchGate-Academia.edu for giving visibility to professional results. For older scholars in the 35-44 and $55^{+}$groups a greater number of motivations were relevant for using both LinkedIn and ResearchGateAcademia.edu. This result could be understood with the central position that senior academics occupy within the networks (Jordan, 2014; Manca \& Ranieri; 2017), which motivate them to use professional social network sites for a variety of reasons, from maintaining networks to strengthening them, from disseminating research results to self-promotion.

Even gender was found relevant, though to a limited extent, in shaping motivations for Facebook, LinkedIn, Blog-Wiki, and ResearchGate-Academia.edu. Interestingly, the motivation "To be part of a professional community" only occurs as relevant for female scholars in the use of LinkedIn, when data on motivations are crossed with gender. It would be an overestimation to conclude that women have more collaborative habits and attitudes towards academic life, when compared to men. However, as observed by Zhu (2014), to reduce gender inequality in academia where women are not well represented in academic positions and publish less than men, they may adopt new forms of scholarly communication based on the use of social media to find new opportunities to collaborate with colleagues within a professional community. 


\section{Limitations}

Although it constituted one of the first extensive surveys in the field, the study presents a number of limitations. First, the target population was located in a single country. Second, the methodological approach adopted (a self-reported study) prevents extensive generalization of the results and should be combined with observed measures or qualitative approaches. Third, the survey was affected by a low level of response rate that identified a sample of responses with a strong bias in terms of (either positive or negative) perceived interest and importance of the topic.

\section{Conclusion and Implications for Theory, Practice, and Research}

This paper presented and discussed the results of a study investigating Italian university scholars' motivations to adopt social media sites for scholarly communication. Motivations were analyzed in combination with factors such as frequency of use, gender, age, years of teaching, academic title, and disciplinary field. The results show that for the most used sites, the influence of variables examined in shaping scholars' attitudes towards social media use is greater. Among the variables analyzed, age, years of teaching, and disciplinary field were found as relevant factors especially for LinkedIn and ResearchGate-Academia.edu, while gender and academic title showed limited impact on scholars' motivations for all social media sites considered in the study.

Our findings do not allow us to draw general conclusions that are transversally viable for all the examined tools, since each presents distinctive patterns of appropriation. However, two general trends that may have an impact on critical reflection about open and networked digital scholarship seem to emerge. First, we acknowledged an increase in the preference of professional academic social media sites. On one side, this is completely reasonable; the higher the number of tools, the greater the specialization with dedicated features matching academic needs. On a practical level, there would be no reasons for not using more effective tools; however, this tendency towards specialization might reintroduce boundaries and enclosures, leading to the constitution of closed communities of experts. To a certain extent, this is understandable in so far as it is linked to Wittgenstein's (1953) concept of a "language game," namely the linguistic game that academics play when they converse with each other and create scientific knowledge. At the same time, this tendency seems to contrast with the ideology of open and distributed digital scholarship as intended by scholars like Weller (2011) and Stewart (2015). Indeed, generic social media sites such as blogs or Twitter may stretch social boundaries, enabling more powerful mechanisms of serendipity, hybridization, and cross-fertilization than those generated by specialized academic social media sites.

Second, we found that disciplinary field has a significant impact on academics' motivations and practices. This seems to obstruct the development of an open culture among academics, preventing cross-disciplinarity and reinforcing subject matter enclosures where experts from a specific field converse with those in the same field. In some way, we need to account for the tensions between specialization and openness, which call for further discussion about the challenges of open and networked digital scholarship.

Tensions emerge even in the practice of networked scholarship, whereby the lack of awards and institutional support may weaken academics' incentive to adopt open digital practices. Given that sustaining the values of open science may lead to an increase in global knowledge (Pearce, Weller, Scanlon, \& Ashleigh, 2010), academic institutions, and policy makers should promote open publishing through concrete initiatives and incentives. For instance, publications supported by public funds should be released under Creative Commons licences as a public good, while academic libraries should increase the visibility of Open Access publications through institutional databases which collect and disseminate publications to a wide public. Advancements 
may also concern the technological sphere. Since social media sites can be seen as micro-systems that influence the way connectivity and sharing mechanisms are built to correspond to the user's technical skills and preferences (van Dijck, 2013), designers should conceive and implement technical features enabling the spread of open culture and greater cross-disciplinarity.

As for future developments of research, additional variables such as job security could be taken into consideration to better highlight the diverse motivations which bring junior and senior academics to use social media sites. Moreover, further data analysis could be conducted to identify users' profiles according to all variables considered in the study and to explore whether an association may be found between users' profile and main motivations. This would help gain more knowledge of scholars' reasons for using social media for scholarly purposes. Another issue that deserves attention from the community of researchers, which is notoriously affected by gender disparities, is the influence of gender on differential motivations to use social media. Though gender did not emerge as a relevant factor, less individualistic reasons to adopt social media were found only when crossing data with gender and women showed more community-oriented aptitudes. Deeper understanding of this data would contribute to advances on whether social media may provide an opportunity to reduce existing discrimination against women in academia.

\section{References}

Al-Aufi, A., \& Fulton, C. (2015). Impact of social networking tools on scholarly communication: A crossinstitutional study. The Electronic Library, 33(2), 224-241.

Al-Aufi, A., \& Genoni, P. (2010). An investigation of digital scholarship and disciplinary culture in Oman. Library Hi Tech, 28(3), 414-432.

Almousa, O. (2011). Users' classification and usage-pattern identification in academic social networks. In Proceedings of the IEEE Jordan Conference on Applied Electrical Engineering and Computing Technologies AEECT (pp. 1-6). New York, NY: IEEE.

Boyer, E. L. (1990). Scholarship reconsidered: Priorities of the professoriate. Princeton, NJ: Carnegie Foundation for the Advancement of Teaching.

Costa, C. (2013). The participatory Web in the context of academic research: Landscapes of change and conflicts (Unpublished doctoral dissertation). University of Salford, England. Retrieved from http://usir.salford.ac.uk/28369/

Dahlstrom, E. (2012). ECAR study of undergraduate students and information technology. Louisville, CO: EDUCAUSE Center for Applied Research.

Donelan, H. (2016). Social media for professional development and networking opportunities in academia. Journal of Further and Higher Education, 4O(5), 706-729.

El-Berry, D. K. (2015). Awareness and use of academic social networking sites by the academic staff at the South Valley University in Egypt. Journal of Library and Information Sciences, 3(2), 115-132.

Elsayed, A. M. (2016). The use of academic social networks among Arab researchers: A survey. Social Science Computer Review, 34(3), 378-391. 
Goodfellow, R. (2013). Scholarly, digital, open: an impossible triangle? Research in Learning Technology, $21,1-15$.

Greenhow, C., \& Gleason, B. (2014). Social scholarship: Reconsidering scholarly practices in the age of social media. British Journal of Educational Technology, 45(3), 392-402.

Gruzd, A., \& Goertzen, M. (2013). Wired academia: Why social science scholars are using social media. In Proceedings of the 46th Hawaii International Conference on System Sciences (HICSS), IEEE, 33323341.

Gu, F., \& Widén-Wulff, G. (2011). Scholarly communication and possible changes in the context of social media. The Electronic Library, 29(6), 762-776.

Harley, D., Acord, S. K., Earl-Novell, S., Lawrence, S., \& King, C. J. (2010). Assessing the future landscape of scholarly communication: An exploration of faculty values and needs in seven disciplines. UC Berkeley, CA: Center for Studies in Higher Education. Retrieved from http://escholarship.org/uc/item/15x7385g

Jamali, H. R., Nicholas, D., \& Herman, E. (2016). Scholarly reputation in the digital age and the role of emerging platforms and mechanisms. Research Evaluation, 25(1), 37-49.

Jeng, W., He, D., \& Jiang, J. (2015). User participation in an academic social networking service: A survey of open group users on Mendeley. Journal of the Association for the Information Science and Technology, 66(5), 890-904.

Jordan, K. (2014). Academics and their online networks: Exploring the role of academic social networking sites. First Monday, 19(1).

Kieslinger, B. (2015). Academic peer pressure in social media: Experiences from the heavy, the targeted and the restricted user. First Monday, 2o(6).

Lupton, D. (2014). 'Feeling Better Connected': Academics' Use of Social Media. Canberra: News \& Media Research Centre, University of Canberra.

Manca, S. (2014, June). I Social Media nell'università italiana. Diffusione degli usi personali, didattici e professionali negli Atenei italiani [Social Media in Italian universities. Extent of personal, teaching and professional use in Italian higher education and research]. ITD-CNR Technical Report. Retrieved from http://tinyurl.com/gt27bes

Manca, S., \& Ranieri, M. (2016a). Facebook and the others. Potentials and obstacles of Social Media for teaching in higher education. Computers \& Education, 95, 216-230.

Manca, S., \& Ranieri, M. (2016b). "Yes for sharing, no for teaching!": Social Media in academic practices. The Internet and Higher Education, 29, 63-74.

Manca, S., \& Ranieri, M. (2017). Exploring Digital Scholarship. A Study on Use of Social Media for Scholarly Communication among Italian Academics. In Esposito A. (Ed.), Research 2.o and the Impact of Digital Technologies on Scholarly Inquiry (pp. 116-141). Hershey, PA: IGI Global. 
Maron, N. L., \& Smith, K. K. (2009). Current models of digital scholarly communication: Results of an investigation conducted by Ithaka for the association of research libraries. The Journal of Electronic Publishing, 12(1).

Moran, M., Seaman, J., \& Tinti-Kane, H. (2012). Blogs, Wikis, Podcasts and Facebook: How today's higher education faculty use social media. Boston, MA: Pearson Learning Solutions and Babson Survey Research Group.

Nández, G., \& Borrego, A. (2013). Use of social networks for academic purposes: a case study. The Electronic Library, 31(6), 781-791.

Nentwick, M., \& König, R. (2014). Academia goes Facebook? The potential of social network sites in the scholarly realm. In S. Bartling, \& S. Friesike (Eds.), Opening science: The evolving guide on how the internet is changing research, collaboration and scholarly publishing (pp. 107-124). Berlin: Springer.

Niyazov, Y., Vogel, C., Price, R., Lund, B., Judd, D., Akil, A., ... Shron, M. (2016). Open access meets discoverability: Citations to articles posted to Academia.edu. PLOS ONE, 11(2): e0148257, 1-41.

Ortega, J. L. (2015). Disciplinary differences in the use of academic social networking sites. Online Information Review, 39(4), 520-536.

Pearce, N., Weller, M., Scanlon, E., \& Ashleigh, M. (2010). Digital scholarship considered: How new technologies could transform academic work. In Education, 16(1), 33- 44.

Procter, R., Williams, R., Stewart, J., Poschen, M., Snee, H., Voss, A., \& Asgari-Targhi, M. (2010). Adoption and use of Web 2.o in scholarly communications. Philosophical Transactions of the Royal Society, 368(1926), 4039-4056.

Rowlands, I., Nicholas, D., Russell, B., Canty, N., \& Watkinson, A. (2011). Social media use in the research workflow. Learned Publishing, 24(3), 183-195.

Scanlon, E. (2014). Scholarship in the digital age: Open educational resources, publication, and public engagement. British Journal of Educational Technology, 45(1), $12-23$.

Segado-Boj, F., Domínguez, M. A. C., \& Rodríguez, C. C. (2015). Use of Twitter among Spanish communication-area faculty: Research, teaching and visibility. First Monday, 6(1).

Stewart, B. E. (2015). In abundance: Networked participatory practices as scholarship. International Review of Research in Open and Distributed Learning, 16(3), 318-340.

Thelwall, M., \& Kousha, K. (2014). Academia.edu: Social Network or Academic Network? Journal of the Association for Information Science and Technology, 65(4), 721-731.

van Dijck, J. (2013). The culture of connectivity. A critical history of social media. Oxford, UK: Oxford University Press.

Veletsianos, G. (2016). Social media in academia: Networked scholars. New York, NY: Routledge. 
Veletsianos, G., \& Kimmons, R. (2012). Networked participatory scholarship: Emergent techno-cultural pressures toward open and digital scholarship in online networks. Computers \& Education, 58(2), 766-774.

Weisberg, H. F., \& Bowen, B. D. (1977). An introduction to survey research and data analysis. San Francisco, CA: WH. Freeman and Company.

Weller, M. (2011). The digital scholar. How technology is transforming scholarly practice. London/New Delhi/New York/Sydney: Bloomsbury.

Wittgenstein, L. (1953). Philosophical investigations. Hoboken, NJ: Wiley-Blackwell.

Zhu, Y. (2014). Seeking and sharing research information on social media: A 2013 survey of scholarly communication. In A. Rospigliosi, \& S. Greener (Eds.), Proceedings of European Conference on Social Media ECSM 2014 (pp. 705-712). 10-11 July 2014, University of Brighton. Brighton, UK: Academic Conferences \& Publishing International.

\section{Athabasca}

University

(c) (†) 